Отримано: 17.07.2019 р.

Прорецензовано: 23.07.2019 p.

Прийнято до друку: 10.08.2019 р.

e-mail: mar4yk80@ukr.net

DOI: 10.25264/2409-6806-2019-28-39-46
Марчук В. Державні банки Волинського воєводства в 1921-1939 роках. Наукові записки Національного університету «Острозька академія». Серія «Історичні науки». Острог, 2019. Вип. 28. С. 39-46.

\title{
Володимир Марчук
}

\section{ДЕРЖАВНІ БАНКИ ВОЛИНСЬКОГО ВОЄВОДСТВА В 1921-1939 РОКАХ}

У статті аналізується прочес інституиійного розвитку державного банківського сектору у Волинському воєводстві у міжвоєнний період. Встановлено, щцо за цей час на території Волинського воєводства польською владою було організовано дієву систему приватних та державних банків. Визначено особливості функиіонування державних банків Волинського воєводства. Окрема увага приділена участі державних банків у фінансуванні аграрного сектора економіки краю у міжвоєнний nepiod.

Ключові слова: Друга Річ Посполита, Волинське воєводство, міжвоєнний період, державні банки, Державний сільськогосподарський банк, Банк господарства крайового.

\section{Volodymyr Marchuk}

\section{STATE BANKS OF THE VOLHYNIAN VOIVODESHIP, 1921-1939}

The article analyses the institutional development of the governmental banking sector in the Volhynian Voivodeship during the interwar period. It has been found out that during this time the local Polish authorities organized an acting system of private and state banks, which was functioning on the basis of the banking right which was enacted by the order of the President of Poland dated from the 17th March 1928. The establishment and functioning of the credit and banking system of independent Poland during two interwar decades was taking place at highly difficult times: inflation in 1918-1923, an economic crisis in 1925, the world economic crisis in 1929-1933. The main tasks of the state banks in the interwar Poland were: granting a loan for the landlords (big, middle and lower-class) and a financial help in the agrarian reform, which included three important elements - the parceling (selling small ploughlands to the countrymen), the consolidation (the union of separate parts of the peasant land into one) and the settlement (a resettlement of the polish military men and civil colonists across the Western Volhyn) and also the financial support of the land reclamation. Apart from that bank played the role of the state funds' administrator that were appointed to help the agriculture (the recreation of the households that were destroyed by the war, the help in feeding of the cattle, fish) or appointed for special nationwide actions, connected with farming (the creation of the grain, bread reserves and elevators). The state banks in the period between two wars became the main financial reliance of the villages' population and the programs, which were held with the assistance of their financial resources, brought the peasant farms closer to the market.

Key words: Second Polish Republic, Volhynian Voivodeship, interwar period, state banks, National Bank for Agriculture, Bank Gospodarstwa Krajowego (National Economy Bank).

Постановка проблеми. Грунтовне та об'єктивне вивчення економіки країни неможливе без дослідження функціонування її фінансової системи. Банківський сектор становить одну з складових цієї системи. Банківські інституції відігравали важливу роль в підтриманні економічної стабільності Польської держави у міжвоєнний період і розвивалися в міру розвою власне самої держави. В зв'язку з слабкістю системи приватних банків, головний тягар відповідальності за фінансову систему країни лежав на державних банках.

Аналіз досліджень і публікацій. Питання діяльності банків та інших кредитно-банківських установ Другої Речі Посполитої лише частково висвітлені в працях українських та польських дослідників. Історії банківської справи міжвоєнної Польщі до 1932 р. присвячена робота Г.Новака [27]. Повоєнна історіографія проблеми діяльності банків представлена роботами В. Моравського [23] [24] [25] та публікаціями 3. Ландау [17] [18] [19] [20], 3. Карпіньського [12], 3. Федоровича [10], В.Яворського [16], Р. Шльонзака [31], А. Нєзгоди [26], У. Загури-Йоншти [34], С. Флейтерського [9]. Крім того, з'явилося і цілий ряд публікацій присвячених різним аспектам роботи окремих банків: Польського банку [11], Державного сільськогосподарського банку [28], Торгівельного банку в Варшаві [21], 
Банку господарства крайового [29] та ін.. Серед публікацій українських науковців, які торкаються даної проблематики варто згадати роботи О. Бурунової [1;2] та Т. Никитюк [8]. Разом з тим, ціла низка аспектів функціонування кредитно-банківської системи міжвоєнної Польщі залишаються поза увагою науковців і тому існує необхідність подальшої розробки цієї теми.

Мета дослідження - здійснити спробу встановити особливості розвитку державного банківського сектору Волинського воєводства у міжвоєнне двадцятиліття.

Виклад основного матеріалу. У соціально-економічному житті міжвоєнної Польщі достатньо гостро стояло питання розвитку кредитно-банківської системи. На території Волині вона багато в чому повторювала систему, яка сформувалася на межі XIX - XX ст. в Російській імперії. Цілком логічною була концентрація банківських установ у найбільших містах воєводства, в першу чергу Луцьку, Рівному, Ковелі та ін.

Кредитно-банківська система Другої Речі Посполитої міжвоєнного періоду функціонувала на основі банківського права введеного в дію розпорядженням Президента Польщі від 17 березня 1928 р., яке запроваджувало обмеження, що стосувалися пропорцій між зобов'язаннями банку та його власним капіталом. Розмір статутного капіталу визначався не лише організаційно-правовою формою кредитно-банківської установи, а й місцезнаходженням її головного офісу. Так, сума засновницького капіталу для банків короткострокового кредиту повинна була дорівнювати: у Варшаві 2500 000, у Кракові, Львові, Познані, Катовіце і Лодзі - 1500 000, в інших містах - 1000000 злотих, а для іпотечних банків - 5000000 злотих [30, s. 676]. Крім того, банкам заборонялося займатися торгівельною діяльністю, а також здійснювати банківську діяльність через товариства з обмеженою відповідальністю. Впроваджувалися і правила, що стосувалися назв установ, які працювали в кредитно-банківській сфері. Назву «банк», могли використовувати лише акціонерні товариства, командитні товариства та банки міжкомунальних спілок. Кредитні кооперативи могли вживати таку назву, але обов'язково $з$ додаванням прикметника «кооперативний» або «народний» [30, s. 676].

Становлення і функціонування кредитно-банківської системи незалежної Польської держави у міжвоєнне двадцятиліття відбувалося у вкрай важкі моменти.

По-перше, в 1918 - 1923 рр. в країні панувала інфляція, яка в 1923 р. переросла в гіперінфляцію. Якщо наприкінці 1919 р. один долар США коштував 110 польських марок, вкінці 1920 р. - 590, наприкінці 1922 р. - 17 800, то в червні 1923 р. - 104 тис., а в жовтні цього ж року - 350 тис. польських марок. У листопаді 1923 р. в обіг була випущена банкнота номіналом в 10 млн. польських марок, а інфляція далі знецінювала польську грошову одиницю. Станом на 31 грудня 1923 р. один долар США коштував 6375000 польських марок, а вкінці березня 1924 р. - 9250000 [24, s. 33]. Інфляційний процес початку 1920-х років фактично знецінив капітал польських банків того часу.

По-друге, кредитно-банківська система Польщі, піддалася серйозному випробуванню під час економічної кризи 1925 р. Основними причинами якої стали: польсько-німецька митна війна, поява дефіциту бюджету і несприятливий торгівельний баланс. Влітку 1925 р., після обвалу недавно введеної нової національної валюти - польського злотого, почалась атака клієнтів на банки. Ця банківська криза показала слабкість приватних банків і загострила типові для посткризового періоду проблеми з ліквідністю.

По-трете, світова економічна криза 1929-1933 рр. достатньо сильно вдарила по польській економіці і кредитно-банківській системі зокрема. I знову в першу чергу постраждали приватні банки.

Кредитно-банківська система Польської держави у міжвоєнний період мала традиційну структуру і складалася 3 державних, комунальних, приватних та кооперативних банків і небанківських установ.

Таблиия 1

Розподіл кредитно-банківських установ за регіонами на 31.12.1938 p.

\begin{tabular}{|c|c|c|c|c|c|c|c|c|c|c|}
\hline \multirow[b]{2}{*}{ Воєводство } & \multirow{2}{*}{ 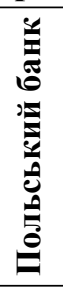 } & \multirow{2}{*}{ 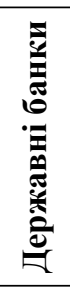 } & \multirow{2}{*}{ 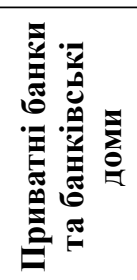 } & \multirow{2}{*}{ 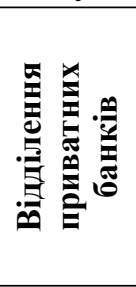 } & \multirow{2}{*}{ 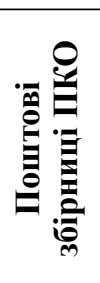 } & \multirow{2}{*}{ 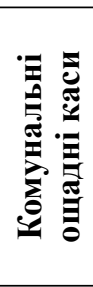 } & \multirow{2}{*}{ 国 } & \multirow{2}{*}{ 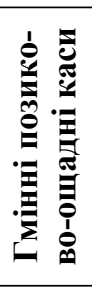 } & \multicolumn{2}{|c|}{\begin{tabular}{|c|}
$\begin{array}{c}\text { Каси безвідсотко- } \\
\text { вих позичок }\end{array}$ \\
\end{tabular}} \\
\hline & & & & & & & & & 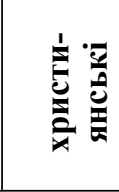 & 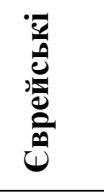 \\
\hline м. Варшава & 2 & 4 & 16 & 15 & 57 & 6 & 94 & - & 33 & 46 \\
\hline Варшавське & 3 & - & - & - & 312 & 34 & 364 & 195 & 69 & 105 \\
\hline
\end{tabular}




\begin{tabular}{|l|c|c|c|c|c|c|c|c|c|c|}
\hline Лодзьке & 3 & 1 & 7 & 5 & 223 & 28 & 285 & 155 & 54 & 60 \\
\hline Келецьке & 4 & 2 & 1 & 5 & 264 & 22 & 348 & 179 & 55 & 92 \\
\hline Люблінське & 3 & 2 & 1 & 1 & 249 & 18 & 278 & 196 & 27 & 92 \\
\hline Білостоцьке & 3 & 2 & 1 & 1 & 160 & 9 & 191 & 28 & 26 & 95 \\
\hline Віленське & 1 & 2 & 5 & 3 & 184 & 8 & 175 & 31 & 46 & 73 \\
\hline Новогрудське & 1 & - & - & 1 & 139 & 8 & 145 & - & 13 & 41 \\
\hline Поліське & 2 & 2 & - & - & 107 & 9 & 132 & 26 & 10 & 47 \\
\hline Волинське & 2 & 2 & - & - & 216 & 14 & 274 & 78 & 19 & 56 \\
\hline Познаньське & 5 & 2 & 5 & 9 & 478 & 89 & 449 & 50 & 26 & 4 \\
\hline Поморське & 8 & 5 & 1 & 15 & 466 & 75 & 361 & 37 & 48 & 5 \\
\hline Сілезьке & 3 & 2 & 7 & 14 & 195 & 42 & 232 & - & 4 & 7 \\
\hline Краківське & 4 & 4 & 3 & 10 & 374 & 28 & 518 & - & 48 & 64 \\
\hline Львівське & 4 & 3 & 6 & 13 & 390 & 42 & 844 & - & 65 & 79 \\
\hline Станіславське & 2 & 2 & - & 3 & 157 & 18 & 405 & - & 28 & 39 \\
\hline Тернопільське & 1 & - & 1 & 1 & 196 & 18 & 502 & - & 40 & 54 \\
\hline ВСьОГО & 51 & 35 & 54 & 96 & 4167 & 468 & 5597 & 975 & 611 & 959 \\
\hline
\end{tabular}

Складено на основі даних: Mały Rocznik Statystyczny. 1939. Warszawa, 1939. S. 210

Як видно з таблиці 1, на території Волинського воєводства станом на кінець 1938 р. були відсутні приватні банки та їхні відділення, таким чином кредитно-банківський сектор тут був представлений державними банками та різного роду кредитно-ощадними касами.

Державний банківський сектор Другої Речі Посполитої було створено кількома заходами уряду. 7 лютого 1919 р. на підставі декрету, виданого Юзефом Пілсудським, було створено Поштову ощадну касу (Pocztowa Kasa Oszczędności) (далі ПКО), яка підпорядковувалася Міністру пошти та телеграфу [25, s. 49]. Завданням цієї установи було нагромадження заощадження населення через мережу поштових відділень, розміщених на всій території Польщі. Сферою діяльності тодішньої ПКО були: оборот заощаджень, купівля, продаж, дисконт та зберігання цінних паперів; інкасо векселів та міжнародні перекази. У 1920 р. підпорядкування банку Міністерству пошти і телеграфу було ліквідовано, натомість установа отримала статус окремої юридичної особи і стала державним банком з гарантіями та під контролем держави. У своїй діяльності ПКО керувалася Розпорядженням Президента Другої Речі Посполитої від 27 червня 1924 р. [25, s. 49].

Першим спеціалізованим державним банком Польської держави став Польський державний сільськогосподарський банк (Polski Państwowy Bank Rolny), утворений відповідно до Закону Польщі від 5 лютого 1919 року [33], який в 1921 р. був перейменований в Державний сільськогосподарський банк (далі ДСБ) (Państwowy Bank Rolny) [25, 46]. Основні його завдання: виділення кредитів землевласникам (як великим і середнім, так і дрібним) та фінансова допомога в реалізації аграрної реформи, яка включала в себе три важливі складові - парцеляцію (продаж землі селянам невеликими наділами), комасацію (об’єднання розрізнених селянських земель у одну ділянку) і хуторизацію, або осадництво (розселення по Західній Волині польських військових і цивільних колоністів), а також фінансування меліорації земель. Крім того, банк виступав адміністратором урядових фондів, призначених на допомогу сільському господарству (відбудова господарств, знищених війною, допомога відгодівлі худоби), або призначених на спеціальні загальнодержавні акції, пов'язані з землеробством (створення хлібних резервів, елеваторів) [8, с. 83].

Діяльність ДСБ активізувалася у 1926-1928 роках. 3 метою зближення банку з населенням, влада почала розбудовувати мережу провінційних відділень. До 3 відділень у Познані, Львові, Вільно, які існували з 1919 року, у 1927 році було відкрито відділення в Луцьку, Кракові, в 1928 р. - у Гданську, Пінську, Любліні [25, s. 47]. Відділення ДСБ, що обслуговувало Волинське воєводство, знаходилося в Луцьку на вул. Пілсудського, 15.

Другий спеціалізований банк, Банк господарства крайового (Bank Gospodarstwa Krajowego), був утворений розпорядженням Президента Другої Речі Посполитої 30 травня 1924 р. шляхом об'єднання трьох галицьких банків органів самоврядування - Польського крайового банку, Державного банку відбудови та Кредитної установи галицьких міст [25, s. 44-45]. У Волинському воєводстві відділення цього банку розташовувалося у м. Луцьку на вул. Ягелонська, 6, а 31925 р. - і в Рівному, по вул. Французька, 2. До головних завдань новоствореного банку належали: надання довгостро- 
кових кредитів через емісію заставних листів, комунальних, залізничних та банківських облігацій, надання позик органам самоврядування, а також кредитування ощадних установ. Окремі обов' язки мав банк щодо державних та самоврядних підприємств, яким банк допомагав у пошуку коштів. Цінні папери, які емітувалися банком, отримували гарантії скарбниці. Після 1926 р. діяльність Банку господарства крайового концентрувалася на підтримці державних і комунальних установ, військової промисловості і сільського господарства, а також управлінні промисловими закладами, які переходили під контроль держави. Банк також управляв державними цільовими фондами, зокрема фондом допомоги кредитним інституціям, державним будівельним фондом і фондом праці [25, s. 44-45].

Протягом 1924 р. було утворено два нових державних банки - у січні Банк Польський (Bank Polski) і у травні -Банк Польський створювався замість утвореного в грудні 1916 р. німецькими окупаційними властями в Варшавському генерал-губернаторстві емісійного банку, що називався Польська крайова кредитна каса (Polska Krajowa Kasa Pozyczkowa).

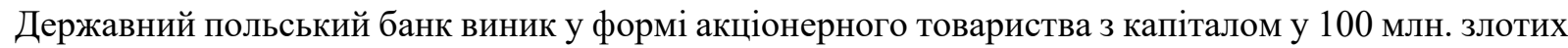
[25, s. 34]. Стартовий капітал банку, було поділено на мільйон акцій вартістю 100 злотих. Акції були іменними. Право одного голосу мали особи, які володіли 25 акціями, але ніхто не міг мати більше як 500 голосів. Раду банку, яка складалася з 12 осіб та 3 заступників вибирали на загальних зборах, а президента і віце-президента банку призначав Президент Польщі. Розкуплені на вільному ринку акції, дозволили банку стати незалежним від інших державних структур та проводити самостійну політику. Головними його завданнями були: емісія грошей, регулювання грошового обігу і надання кредитів під заставу фізичним та юридичним особам, купівля і продаж золота та срібла, іноземної валюти, прийняття депозитів, прийняття вкладів і відкриття рахунків та ін. Однак через кризу 1925 p. Державному польському банку прийшлось зосередити увесь свій капітал на підтримку курсу національної валюти і фактично відмовитися від інших функцій центрального банку країни. Протягом усього періоду існування Другої Речі Посполитої, банк виконував в основному функцію емісійного центру [25, s. 34-37]. У Луцьку відділення державного банку розташовувалося на вулиці Бернардинській, 13. Інше представництво цього банку функціонувало в м. Рівному.

Саме $з$ появою відділень державних Польського банку та Державного сільгосподарського банку було пов'язане поширення неокласицизму в архітектурі. Поява цих інституцій в Волинському воєводстві вимагала певного облаштування їх діяльності. Так, для Луцька у 1925 р. був виконаний, а, 3 часом і реалізований проект будівлі відділення Польського банку авторства В. Баліньського, а в 1928 - проект будівлі ДСБ авторства академіка архітектури Мар'яна Лялевича. На завершальному етапі до проектування Польського банку в Луцьку були залучені варшавські архітектори Ксаверій Мьончиньськи та Станіслав Щесняк, які й увійшли в історію як автори цієї будівлі [7, с. 159-160].

Серед усього асортименту сфер діяльності державних банків, провідним залишалося кредитування. В залежності від термінів надання, ДСБ надавав 3 види кредитів:

- короткотермінові - на період від декількох місяців до 1 року;

- середньотермінові - від 3 до 5 років;

- довготермінові - від 10 до 30 років [6, с. 145].

Право на кредит мали власники малих та середніх господарств. Для отримання позички потрібно було подати до місцевого відділення ДСБ прохання за спеціально розробленим зразком, 3 обов'язковим зазначенням цілей майбутнього використання коштів. Основною умовою отримання кредиту в банку було оформлення права власності на землю - іпотеки. Відсутність іпотечної справи при окружному суді значно звужувала коло можливих клієнтів банку. 3 часом банк зробив певні поступки для осіб, які брали короткотермінові кредити. Однак селяни, які брали позики, зобов'язувалися негайно приступити до врегулювання права власності не пізніше ніж через 1 рік від дня отримання грошей і надати в банк засвідчення відповідного іпотечного відділу про те, що внесок на перше врегулювання іпотеки зроблено. Після цього селяни отримували право переведення кредиту з коротко- довготермінові. Банк мав право на дострокове стягнення всієї суми кредиту, якщо кошти були використані не за призначенням, або господарство було продано до повного погашення позики, або у випадку не надсилання іпотечного засвідчення [8, с. 84].

До 1927 р. всі види банківських кредитів були персональними і надавалися безпосередньо клієнтам, після зазначеного часу ДСБ почав надавати позики через Кредитні товариства, Рільничі товариства, рільничо-торгові та рільничо-переробні кооперативи, повітові та гмінні ощадні каси. Для того, щоб отримати кредит, селянам потрібно було звернутися до гмінної ощадно-позичкової каси, яка 
формувала загальний витяг прохачів та пропоновану для них суму позичок у Луцький відділ банку. Після того, у 3-місячний термін від дати отримання коштів ці установи подавали детальний звіт про розподіл кредитних коштів. Плата за користування банківськими коштами для посередницьких установ становила величину дисконту Польського банку, а як забезпечення використовували їх власні векселі [8, с. 84-85].

Крім того, державні банки видавали ще й спеціальні кредити. Так, в БГК існувало два види таких кредитів: 1) на який відділення отримувало дотації з центрального відділення; 2) які видавав 3 власних обігових коштів [3, арк. 57]. Кожен з видів спеціальних кредитів мав власний дотаційний рахунок і відсоткову ставку за користування позичкою. Рахунок дотаційний «А»-відсоткова ставка відповідно до ставки Польського банку - для дотацій головного відділення; рахунок дотаційний «В» - відсоткова ставка 71/2 для кредитів: 1) для комунальних позичкових обігових кас, 2) для комунальних позичкових кас завьонзкових, 3) для кооперативів; 4) ... 5) ..., 6) лісові, 7) рибні, 8) комунальні готівкові, 9) індивідуальні, які видавалися на цілі, які не були передбачені в жодній з груп; рахунок дотаційний «С»- відсоткова ставка $8 \%$ для ремісничих кредитів; рахунок дотаційний «Е»- безвідсотковий - кредити 3 цього рахунку розприділялися лише за вказівкою центрального відділення; рахунок дотаційний «Н» - відсоткова ставка $6 \%$ - для пільгових ремісничих кредитів; рахунок дотаційний «F» - відсоткова ставка 8\% кредит на будівництво з Державного Будівельного Фонду (далі ДБФ); рахунок дотаційний «К» - відсоткова ставка $9 \%$ кредит на будівництво, який видавався 3 власних обігових коштів [3, арк. 58-59].

Державний сільськогосподарський банк короткотермінові позички видавав на спеціально визначені цілі: на штучні добрива, на купівлю вогнетривких покрівельних матеріалів, на корми для худоби та риби, на насіння, на вирощування хмелю, на садівництво, на купівлю племінної худоби, на молочарний, бджолярський та інші сільгосподарські промисли. За період, який передував економічній кризі, з 1927 р. до 1930 р. Луцький відділ ДСБ видав близько 30 млн. злотих короткотермінових кредитів, в середньому на одного клієнта припадало від 500 до 1000 зл [5, с. 7]. Сплата кредиту здійснювалася за ставкою $1,5 \%$ понад облікову ставку Польського банку і проводилася ратами (частинами). Для коротко- та середньострокових кредитів виплата боргу розділялася на 2 рати і сплачувалася після завершення одного року від часу отримання грошей [13, s. 11].

Найбільш поширеним видом кредитування ДСБ були довготермінові позички. В залежності від цілей банк виділяв кредити у заставних листах:

- на купівлю землі в зв'язку з парцеляцією;

- на сплату залишку вартості купівлі землі згідно 3 парцеляцією, якщо борг не перевищував 5 років;

- на купівлю земельних ділянок площею до 20 га.

Для встановлення суми довгострокового кредиту ДСБ проводив оцінку вартості землі. Існувало два види такої оцінки:

- оцінка грунту на місці (платна);

- камеральна оцінка зі слів постачальника (безкоштовна) [13, s. 11].

У першому випадку, особа, яка брала кредит могла розраховувати на позичку у розмірі $2 / 3$ вартості грунту на купівлю, або $1 / 2$ вартості на будівництво, покращення родючості землі чи сплату боргів. У випадку камеральної оцінки - сума позики не перевищувала $1 / 3$ вартості землі незалежно від використання кредиту. 3 метою розширення кола користувачів кредитом банк камеральну оцінку проводив у цінах для найкращої якості грунту, але такий кредит не міг перевищувати 20000 у золоті. У залежності від бажання прохача могли оцінюватися також житлові та господарські будівлі, однак їх оцінка не могла перевищувати 30-75\% вартості грунту і вони мали бути обов'язково застраховані. Від початку своєї діяльності і до 1930-х років Луцький відділ банку видав довготермінових кредитів на купівлю землі близько 20 млн злотих в золоті для більш як 4000 покупців землі $[8$, с. 85].

Довгострокові кредити виділялися ДСБ окремим господарствам на час за вибором позичальника. Оплачувалися борги піврічними ратами кожного квітня та жовтня. Відсотки за користування позичкою становили $16,5 \%$ для кредиту на 10 років, $11,6 \%$ - для 20 -річного, $10,36 \%$ - для 30 річного кредиту [8, с. 11].

Особливим видом кредиту ДСБ була позика під заставу зерна. Щоб отримати такий кредит, потрібно було подати прохання у відділення банку в Луцьку до 1 липня поточного року. Позичка виділялася середнім та великим господарствам (понад 50 га) у сумі 50\% від вартості зерна в снопах, або 
$60 \%$ від його вартості в зерні, оціненому по ринкових цінах. Зерно, яке перебувало в заставі мало бути застрахованим принаймні на місяць довше від часу погашення кредиту. Плата за користування кредитом становила $43 / 4 \%$ на рік у 2 ратах без права відстрочення платежів та $1 \frac{1}{2} \%$ від вартості зерна одноразово. Аналогічні кредити видавалися дрібним власникам через повітові ощадкаси, але дещо на інших умовах зокрема в залежності від виду зернових культур: 7 зл. на 100 кг жита чи овесу; 8 зл. на 100 кг ячменю; 10 зл. на 100 кг пшениці під 4,5\% річних [14, s. 3].

Значну увагу державні банки приділяли кредитуванню будівництва. Так, наприклад, Рівненське відділення БГК мало в своїй структурі окремий підрозділ, що займався кредитуванням будівництва. Центральне відділення банку встановило обмеження максимальної суми кредиту на будівництво, яку могло видати відділення. Так, найбільші суми кредиту в 50000 зл. мали право видавати відділення в Кракові, Львові та Лодзі; 25000 зл. - Катовіцах і Познані; 15000 зл. - Познані; 10000 зл. - Любліні, Радомі, Рівному, Станіславі, Вільно і Влоцлавіку. За погодженням з центральним відділенням сума будівельного кредиту могла перевищувати встановлену межу [4, арк. 40]. Цікавим, $\epsilon$ те що клієнтам не виплачувалася повна сума кредиту на будівництво, а ратами (частками) в міру виконання будівельних робіт. Невиплачена сума кредиту записувалася клієнтові на поточний рахунок 3 будівельної позички, звідки проводилися подальше кредитування будівництва. Разом з тим клієнт одночасно міг мати два кредити - і з ДБФ і з коштів банку. На відбудову господарств, які постраждали в роки Першої світової війни, ДСБ населенню Волині до 1930-го року було видано 8,5 млн. зл. під $4 \%$ річних [6, с. 144]. У рамках цієї акції здійснювалася програма розширення використання нових матеріалів та способів будівництва житлових і господарських споруд.

Не залишилися поза увагою ДСБ інвестування у розвиток переробної промисловості та фінансування землеробства. 8 червня 1935 року було видано Ухвалу економічного комітету при польському уряді про виділення через ДСБ 15 мільйонів злотих на фінансування програм технічної розбудови селянських господарств 3 метою сприяння переробки та збуту продукції сільського господарства. Ця ухвала пожвавила виділення ще одного виду кредиту - інвестиційного. Цей вид позик виділявся на такі цілі: на будівництво складів насіння, овочів, фруктів, добрив; на будівництво елеваторів, молочарень, сироварень, гуралень, боєнь, крохмальних заводів. Для того, щоб отримати такий кредит, до прохання потрібно також було включити план будівництва та облаштування проектної інвестиції. Такі кредити на будівництво видавалися на 40 років, на купівлю обладнання - на 20 років під заставу іпотеки. Величина позички не могла перевищувати $80 \%$ вартості будівництва вцілому. Плата за кредит становила $1 \%$ на адміністративні потреби банку, одноразові внески $1 / 4 \%$ на рахунок інвестиційної підкомісії Міністерства сільського господарства та $1 \frac{1}{2} \%$ на покриття витрат банку на доставку коштів. Сплата кредиту проводилася у річних амортизаційних ратах через 1 рік від дати отримання коштів [5, с. 7]. Серед інвестиційних проектів Волинського воєводства особлива увага приділялася будівництву зернових магазинів та елеваторів. У господарствах міжвоєнної Волині вироблялася велика кількість зерна. В період після збору врожаю через відсутність достатнього споживчого попиту на місцях і розвиненої транспортної мережі по постачанню зерна до найближчих ринків збуту виникало значне падіння прибутків землеробів через низький рівень ринкових цін. Ціни на зерно у Волинському воєводстві відрізнялися від загальнопольських у бік зниження від $-0,58$ до $-7,72$ злотих за центнер. У 1936 р. будівництво елеваторів на Волині перейшло з проектної фази у практичну. В цей рік ДСБ видав волинським повітовим ощадним касам на дані цілі в Луцьку -60 тис. зл., Дубно 66 тис.зл., Кременці - 60 тис. зл., Ковелі - 50 тис. зл., Горохові - 40 тис зл. [15, s. 11]. Згодом кредити на будівництво елеваторів набрали форми регіонального кредитування. За посередництвом банку було розроблено типовий технічний план елеватора на 750 тонн зерна з початковим кошторисом будівництва 43 тис. зл. та 6-8 тис. зл. на пристрої для сушіння зерна [8, с. 87].

ДСБ займався пропагандистською роботою та кредитуванням меліорації Волинського Полісся. Починаючи 3 1930-х років у місцевій пресі було розгорнуто широку роз'яснювальну кампанію з метою залучення селян до проведення меліораційних робіт. У 1929 р. Волинське воєводське управління розробило «План меліораційних робіт на 1932-1933рр.», в якому частка державних видатків на меліораційні роботи, асигнованих через ДСБ, складала $1 / 3$ від загальної суми і становила 27,632 млн. зл. [8, с. 88].

Отже, протягом майже двадцятирічного перебування Західної Волині у складі Другої Речі Посполитої тут було сформовано дієву мережу державних банків, які стали фінансовою опорою сільського 
населення краю, а реалізовані при їх сприянні програми дозволили підняти селянські господарства на якісно новий рівень.

\section{Список використаних джерел та літератури:}

1. Бурунова О. Банківська справа в Західній Україні та Польщі напередодні Другої світової війни: історикоекономічний аналіз. Волинь $і$ волиняни у Другій світовій війні: збірник наукових праць. 2012. С. 118-124.

2. Бурунова О. Кредитна політика Державного земельного банку Другої Речі Посполитої в Західній Україні. Фінанси України. 2007. № 3. С. 140-149.

3. Держархів Рівненської обл. (Державний архів Рівненської області). Ф. 40. Оп. 2. Спр. 1. 120 арк.

4. Держархів Рівненської обл. Ф.40. Оп. 2. Спр. 5. 108 арк.

5. Комунікат Рільничого банку. Народний вісник. 1927. Ч. 30.

6. Леоненко П., Бурунова О. Кредитна політика Державного земельного банку Другої Речі Посполитої в Західній Україні. Фінанси України. 2007. № 3. С. 140-149.

7. Михайлишин О. Архітектура і містобудування Західної Волині 1921-1939 pp. Рівне, 2013. 352 с.

8. Никитюк Т. Державний сільськогосподарський банк у системі фінансування аграрної реформи у Волинському воєводстві у 1920-1930 pp. Збірник наукових праць Луцького держсавного технічного університету. Серія «Природокористування та ресурсозбереження». Луцьк, 2001. Вип. VII, № 4. С. 82-88.

9. Флейтерський С. Комерційна банківська справа в Польщі до 1989 р. Еволющія банківської справи Польщі. Люблін, 2006. С. 18-30.

10. Fedorowicz Z. Początki działalności kredytowej w Polsce przedwrześniowej. Wiadomości Narodowego Banku Polskiego. 1968. nr 11.

11. Karpiński Z. Bank Polski 1924-1939. Warszawa 1958.

12. Karpiński Z. Bankowość polska przed pięćdziesięciu laty. Wiadomości Narodowego Banku Polskiego. 1968. $\mathrm{Nr} 11$.

13. Komunikat Państwowego banku Rolnego. Luck, 1928.

14. Kredyt pod zastaw produktów rolnych. Komunikat gospodarczy Wolyńskiej Izby Rolniczej. Łuck, 1934. № 8.

15. Kredyty na budowę magazynów zbożowych. Komunikat gospodarczy Wolyńskiej Izby Rolniczej. Łuck, 1936. № 5. S. 11

16. Jaworski W. System kredytowy Polski kapitalistycznej. Wiadomości Narodowego Banku Polskiego. 1957. $\mathrm{Nr} 7-8$.

17. Landau Z. Bankowość polska w latach 1924-1929. Bank i Kredyt. 1970. Nr. 4.

18. Landau Z. Działalność banków w Polsce w latach wielkiego kryzysu gospodarczego (1930-1935). Finanse. 1976. $\mathrm{Nr} 6$.

19. Landau Z. Bankowość polska w latach 1936-1939. Bank i Kredyt. 1986. Nr 6.

20. Landau Z. Główne tendencje rozwojowe bankowości w II Rzeczypospolitej. Bank i Kredyt. 1978. Nr 11.

21. Landau Z., Tomaszewski J., Bank Handlowy w Warszawie S.A. Historia i rozwój 1870-1970. Warszawa, 1970.

22. Mały Rocznik Statystyczny. 1939. Warszawa, 1939.

23. Morawski W. Banki komercyjne na wschodnich ziemiach II Rzeczypospolitej. Acta Archeologica Lodziensia. 2015. Nr 61. S. 85-94.

24. Morawski W. Bankowość prywatna w II Rzeczypospolitej. Warszawa, 1996. 185 s.

25. Morawski W. Słownik historyczny bankowości polskiej do 1939 r. Warszawa, 1998. 208 s.

26. Niezgoda A. Rodzaje i formy prawne banków (w świetle doświadczeń okresu międzywojennego). Studia Prawnicze. 1995. Nr 1/4.

27. Nowak H. Bankowość w Polsce. Warszawa, 1932.

28. Nowak M. Państwowy Bank Rolny w Drugiej Rzeczypospolitej. Zeszyty Naukowe Uniwersytetu Jagiellońskiego. Prace Prawnicze. 1988. Nr 128.

29. Nowak M., Zasady systemu kredytowego Banku Gospodarstwa Krajowego w okresie międzywojennym. Zeszyty Naukowe Uniwersytetu Jagiellońskiego. Prace Prawnicze. 1976. Nr 70.

30. Rozporządzenie Pzezydenta Rzeczypospolitey z dnia 17 marca 1928 r. o prawie bankowem. Dziennik Ustaw Rzeczypospolitey Polskiej. Warszawa, 1928. № 34. Poz. 321. S. 675-684.

31. Ślązak R. Banki polskie II Rzeczypospolitej. Przegląd Techniczny. 1988. Nr 8.

32. Ustawa z dnia 10 czerwca 1921 r. w przedmiocie utworzenia Państwowego Banku Rolnego. Dziennik Ustaw Rzeczypospolitey Polskiej. Warszawa, 1921. № 59. Poz. 369. S. 988-996.

33. Ustawa $z$ dnia 4 lutego 1921 r. o unormowaniu stanu prawno-politycznego na ziemiach, przyłączonych do obszaru Rzeczypospolitej na podstawie umowy o preliminaryjnym pokoju i rozejmie podpisanej w Rydze dnia 12 października 1920 r. Dziennik Ustaw Rzeczypospolitey Polskiej. Warszawa, 1921. № 16. Poz. 93. S. $216-217$.

34. Zagóra-Jonszta U. Sektor bankowy w Drugiej Rzeczypospolitej. Prace Naukowe Uniwersytetu Ekonomicznego we Wrocławiu. Wrocław, 2012. Nr. 245. S. 674-684

\section{References}

1. Burunova O. Bankivska sprava v Zakhidnii Ukraini ta Polshchi naperedodni Druhoi svitovoi viiny: istorykoekonomichnyi analiz. Volyn i volyniany u Druhii svitovii viini: zbirnyk naukovykh prats. 2012. S. 118-124.

2. Burunova O. Kredytna polityka Derzhavnoho zemelnoho banku Druhoi Rechi Pospolytoi v Zakhidnii Ukraini. Finansy Ukrainy. 2007. № 3. S. 140-149.

3. DARO (Derzhavnyi arkhiv Rivnenskoi oblasti). F. 40. Op. 2. Spr. 1. 120 ark. 
4. DARO. F.40. Op. 2. Spr. 5. 108 ark.

5. Komunikat Rilnychoho banku. Narodnyi visnyk. 1927. Ch. 30.

6. Leonenko P., Burunova O. Kredytna polityka Derzhavnoho zemelnoho banku Druhoi Rechi Pospolytoi v Zakhidnii Ukraini. Finansy Ukrainy. 2007. № 3. S. 140-149.

7. Mykhailyshyn O. Arkhitektura i mistobuduvannia Zakhidnoi Volyni 1921-1939 rr. Rivne, 2013. 352 s.

8. Nykytiuk T. Derzhavnyi silskohospodarskyi bank u systemi finansuvannia ahrarnoi reformy u Volynskomu voievodstvi u 1920-1930 rr. Zbirnyk naukovykh prats Lutskoho derzhavnoho tekhnichnoho universytetu. Seriia «Pryrodokorystuvannia ta resursozberezhennia». Vypusk VII, № 4. Lutsk, 2001. S. 82-88.

9. Fleiterskyi S. Komertsiina bankivska sprava v Polshchi do 1989 r. Evoliutsiia bankivskoi spravy Polshchi. Liublin : Un-t Marii Kiuri-Skladovskoi, 2006. S. 18-30.

10. Fedorowicz Z. Początki działalności kredytowej w Polsce przedwrześniowej. Wiadomości Narodowego Banku Polskiego. 1968, nr 11

11. Karpiński Z. Bank Polski 1924-1939. Warszawa 1958.

12. Karpiński Z. Bankowość polska przed pięćdziesięciu laty. Wiadomości Narodowego Banku Polskiego. 1968, nr 11.

13. Komunikat Państwowego banku Rolnego. Luck, 1928.

14. Kredyt pod zastaw produktów rolnych. Komunikat gospodarczy Wotyńskiej Izby Rolniczej. Łuck, 1934. № 8, S. 3-4

15. Kredyty na budowę magazynów zbożowych. Komunikat gospodarczy Wolyńskiej Izby Rolniczej. Łuck, 1936. № 5, S. 11

16. Jaworski W. System kredytowy Polski kapitalistycznej. Wiadomości Narodowego Banku Polskiego. 1957, nr 7-8.

17. Landau Z. Bankowość polska w latach 1924-1929. Bank i Kredyt. Nr. 4. 1970.

18. Landau Z. Działalność banków w Polsce w latach wielkiego kryzysu gospodarczego (1930-1935). Finanse. 1976, Nr 6.

19. Landau Z. Bankowość polska w latach 1936-1939. Bank i Kredyt. 1986, Nr 6.

20. Landau Z. Główne tendencje rozwojowe bankowości w II Rzeczypospolitej. Bank i Kredyt. 1978, nr 11.

21. Landau Z., Tomaszewski J., Bank Handlowy w Warszawie S.A. Historia i rozwój 1870-1970. Warszawa 1970. 22. Mały Rocznik Statystyczny. 1939. Warszawa, 1939.

23. Morawski W. Banki komercyjne na wschodnich ziemiach II Rzeczypospolitej. Acta Archeologica Lodziensia. Nr 61, S. 85-94

24. Morawski W. Bankowość prywatna w II Rzeczypospolitej. Warszawa, 1996. $185 \mathrm{~s}$.

25. Morawski W. Słownik historyczny bankowości polskiej do 1939 r. Warszawa, 1998. $208 \mathrm{~s}$.

26. Niezgoda A. Rodzaje i formy prawne banków (w świetle doświadczeń okresu międzywojennego). Studia Prawnicze. 1995, nr 1/4.

27. Nowak H. Bankowość w Polsce. Warszawa. 1932.

28. Nowak M. Państwowy Bank Rolny w Drugiej Rzeczypospolitej. Zeszyty Naukowe Uniwersytetu Jagiellońskiego. Prace Prawnicze. 1988, nr 128.

29. Nowak M., Zasady systemu kredytowego Banku Gospodarstwa Krajowego w okresie międzywojennym. Zeszyty Naukowe Uniwersytetu Jagiellonskiego. Prace Prawnicze. 1976. nr 70.

30. Rozporządzenie Pzezydenta Rzeczypospolitey z dnia 17 marca 1928 r. o prawie bankowem. Dziennik Ustaw Rzeczypospolitey Polskiej. Warszawa, 1928. № 34. Poz. 321. S. 675-684.

31. Ślązak R. Banki polskie II Rzeczypospolitej. Przeglad Techniczny. 1988, nr 8.

32. Ustawa z dnia 10 czerwca 1921 r. w przedmiocie utworzenia Państwowego Banku Rolnego. Dziennik Ustaw Rzeczypospolitey Polskiej. Warszawa, 1921. № 59. Poz. 369. S. 988-996.

33. Ustawa z dnia 4 lutego 1921 r. o unormowaniu stanu prawno-politycznego na ziemiach, przyłączonych do obszaru Rzeczypospolitej na podstawie umowy o preliminaryjnym pokoju i rozejmie podpisanej w Rydze dnia 12 października 1920 r. Dziennik Ustaw Rzeczypospolitey Polskiej. Warszawa, 1921. № 16. Poz. 93. S. 216-217.

34. Zagóra-Jonszta U. Sektor bankowy w Drugiej Rzeczypospolitej. Prace Naukowe Uniwersytetu Ekonomicznego we Wroctawiu. Nr. 245. Wrocław, 2012. S. 674-684. 